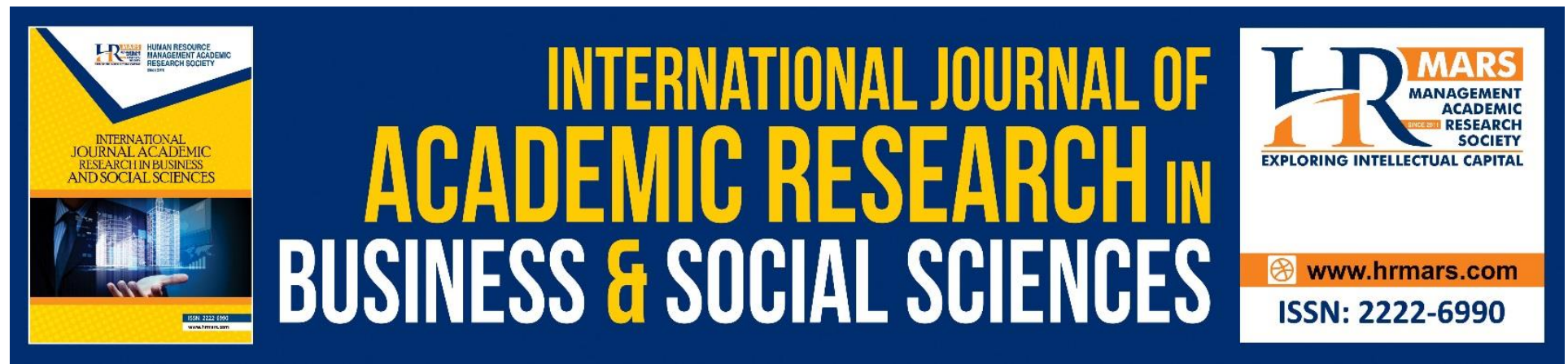

\title{
Assessing the Impact of Macroeconomic Variables And Macroprudential Policy Elements on the Capital Adequacy Ratio
}

Sutina Junos, Masturah Ma'in and Siti Ayu Jalil

To Link this Article: http://dx.doi.org/10.6007/IJARBSS/v11-i8/10740

DOI:10.6007/IJARBSS/v11-i8/10740

Received: 04 June 2021, Revised: 30 June 2021, Accepted: 18 July 2021

Published Online: 06 August 2021

In-Text Citation: (Junos et al., 2021)

To Cite this Article: Junos, S., Ma'in, M., \& Jalil, S. A. (2021). Assessing the Impact of Macroeconomic Variables And Macroprudential Policy Elements on the Capital Adequacy Ratio. International Journal of Academic Research in Business and Social Sciences, 11(8), 390-411.

Copyright: (c) 2021 The Author(s)

Published by Human Resource Management Academic Research Society (www.hrmars.com)

This article is published under the Creative Commons Attribution (CC BY 4.0) license. Anyone may reproduce, distribute, translate and create derivative works of this article (for both commercial and non-commercial purposes), subject to full attribution to the original publication and authors. The full terms of this license may be seen at: http://creativecommons.org/licences/by/4.0/legalcode

Vol. 11, No. 8, 2021, Pg. 390 - 411

Full Terms \& Conditions of access and use can be found at http://hrmars.com/index.php/pages/detail/publication-ethics 


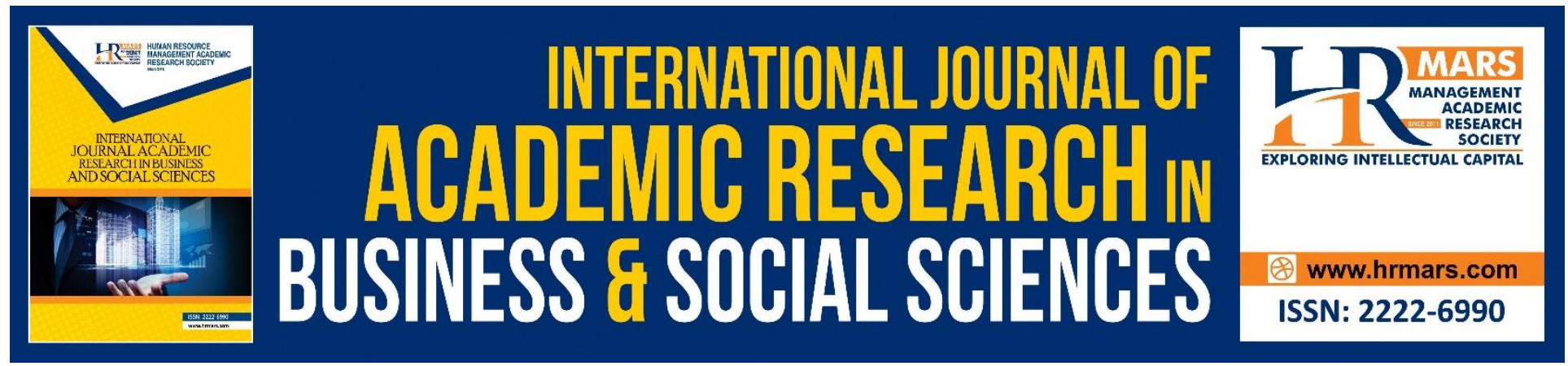

\title{
Assessing the Impact of Macroeconomic Variables And Macroprudential Policy Elements on the Capital Adequacy Ratio
}

\author{
Sutina Junos ${ }^{1}$, Masturah Ma'in ${ }^{2}$ and Siti Ayu Jaliil ${ }^{3}$ \\ ${ }^{1}$ Faculty of Business and Management, Universiti Teknologi MARA Cawangan Negeri Sembilan \\ Kampus Rembau, 71300 Rembau, Negeri Sembilan, ${ }^{2}$ Faculty of Business and Management, \\ Universiti Teknologi MARA, 40450 Shah Alam, Selangor, ${ }^{3}$ Faculty of Business and Management, \\ Universiti Teknologi MARA Cawangan Selangor Kampus Puncak Alam, 42300 Bandar Puncak \\ Alam, Selangor
}

\begin{abstract}
Macroprudential policy is the approach that is specifically aimed at containing systemic risks and maintaining financial stability in a country. One of the key elements of an effective macroprudential policy framework is a system of early warning indicators that signal increased vulnerabilities to financial stability. The most important macroprudential policy indicators that are used to monitor systemic risk are asset quality and liquidity indicators. The key indicator is capital adequacy ratio. It is also the main prudential and structural Islamic Finance indicators (PSIFIs) on the financial soundness and growth of the Islamic banking systems. This study investigates the relationship between the Capital adequacy ratio and different macroeconomic variables and macroprudential policy elements for twenty (20) selected countries from 2008 until 2017. It is documented that there is statistically significant relationship between the capital adequacy ratio and macroeconomic variables such as gross domestic product, balance of payment, money supply and unemployment rate. For the effect of macroprudential policy instruments and institutional factors it shows that these elements are effective in stabilising the banking system fragility.
\end{abstract}

Keywords: Macroprudential Policy, Systemic Risk, Financial Stability, Capital Adequacy Ratio and Banking System Fragility

\section{Introduction}

The Global Financial Crisis (GFC) of 2008 to 2009 has brought a huge impact on the world economy. It began with US Subprime mortgage crisis, explode to housing crisis and quickly grew into a global banking crisis with the investment and merchant banks first absorbing the impact before it spreads to the commercial banks and Islamic banks as well (Krugman, 2009; Hasan \& 
Dridi, 2010). According to Arvai, Prasad and Katayama (2014), the global financial crisis not only triggered major changes in the approach countries take in financial regulation, but it also led to the recognition of the financial stability in order to achieve macroeconomic stability. The main lesson of this crisis is the importance of mitigating systemic financial risks and the need to strengthen the macroprudential approach to supervision and regulation that can identify risks throughout the system and take appropriate actions to maintain financial stability (Kawai \& Morgan, 2012).

Macroprudential policy can be defined as a policy that uses primarily prudential tools to limit systemic or system-wide financial risk, thereby limiting the incidence of disruptions in the provision of key financial services that can have serious consequences for the real economy. According to Kawai and Morgan (2012), there are two main objectives of macroprudential supervision and regulation that are to reduce systemic risk and preserve systemic financial stability. Systemic risk is the risk of collapse in the entire financial system stemming from the breakdown of a single firm. It is a result of undercapitalisation by financial institutions in a market that is increasingly interdependent (Calmes \& Theoret, 2014). Understanding and quantifying this systemic risk is important in ensuring that our financial institutions are adequately capitalised to withstand another financial crisis. Borio (2010) stated that there are two classification of the systemic risks that addressed by macroprudential policy that are time dimension and crosssectional dimension. The time dimension deal with how aggregate risk in the financial system evolves over time.

Systemic risk was a major contributor to the global financial crisis (GFC) 2008 to 2009 and companies that are facing with this systemic risk problem are called "too big to fail." In order to monitor systemic risk, a wide range of macroprudential indicators is used in the previous studies such indicators of bank capital, bank's performance, indicators of liquidity and indebtedness. Other than that the indicators also cover both the domestic and international aspects of the financial system, and include macro, micro and sectoral variables (Lim et al., 2011). The most important macroprudential policy indicators that are used to monitor systemic risk are asset quality and liquidity indicators. The key indicator is capital adequacy ratio. It is also the main prudential and structural Islamic Finance indicators (PSIFIs) on the financial soundness and growth of the Islamic banking systems.

The aim of this research is to examine the relationship between the Capital adequacy ratio with different macroeconomic variables and macroprudential policy elements for twenty (20) selected countries from 2008 until 2017. These selected countries are Bahrain, Bangladesh, Brunei, Egypt, Indonesia, Iran, Jordan, Kuwait, Lebanon, Malaysia, Nigeria, Oman, Pakistan, Palestine, Qatar, Saudi Arabia, Sudan, Tunisia, Turkey and United Arab Emirates (UAE).

\section{Literature Review}

One of the factors that would determine the banking system's resiliency to shocks is the availability of banking capital. According to loan, Balogh and Simona (2013), the main indicator use to assess the banking fragility is capital adequacy ratio (CAR). It is used in the banking system to protect depositor and to promote the stability and efficiency of the global financial system. It is also assists to prevent the banks from taking any excess leverage and becoming insolvent in the process (Mili, Sahut \& Trimeche, 2014). Bank Capital to risk weighted assets measures is used as a macroprudential indicator for capital adequacy ratio (CAR) (Hewaidy \& Alyousef, 2018). This 
macroprudential indicator is calculated using total regulatory capital as the numerator and riskweighted assets as the denominator (ADB, 2015). There are two type of capital that are measure in the formula that are tier one capital which can absorb losses without a bank being required to cease trading and another one is tier two capital which can absorb losses in the event of liquidation and so provides a lesser degree of protection to depositors (Irawan \& Anggono, 2015). The risk weighted assets that take into account are credit risk, market risk and operational risk. The Basel III norms prescribed capital to risk-weighted assets of $8 \%$.

In Turkey, Asarkaya and Ozcan (2007) have studies on the determinants of capital structure in the banking sector from 2002 to 2006. By using the generalized method of moments (GMM) estimators, the finding suggested that economic growth has a positive correlation with capital adequacy ratio. By using GLS regression model, Aktas et al (2015) study on the Determinants of Banks' Capital Adequacy Ratio in South Eastern European Countries from 2007 to 2012. The empirical finding showed that from a sample of 71 commercial banks, the economic growth rate has statistically significant effect in determining CAR for the bank in the SEE region. Other than that, Yahaya et al (2016) investigated the impact of Financial and Economic performance on Capital Adequacy Ratio in Japan. The data were evaluated from 64 regional banks over a period of 10 years from 2005 to 2014. By using panel regression model in their study, GDP growth showed a negative sign with CAR.

Past studies have revealed that inflation rate is one of the determinants that affect capital adequacy ratio and liquidity ratio. In Nigeria, by using Co-Integration analysis technique, Williams (2011) had studied the relationship between capital base and some macroeconomic variables, financial structure, and banking variables during 1980 to 2008 in Nigeria. The study revealed that there is a negative relationship between inflation and banks capital base because inflation erodes banks capital in the most developing economy. Therefore to ensure the inflation rate at a minimum level, the Nigerian government and bank regulators should regulate and strengthen their investment policy. Similarly, Aktas, et al (2015) had studied on the Determinants of Banks' Capital Adequacy Ratio in South Eastern European Countries over a period 2007 to 2012. By using feasible GLS regression model, the result showed that inflation rate has a negative relationship with CAR for the bank in the SEE region. Other than that Yahaya, et al.(2016) have investigated about the impact of Financial and Economic performance on Capital Adequacy Ratio in Japan. The data were evaluated from 64 regional banks over a period of 10 years from 2005 to 2014. By using panel regression model in their study, the result revealed that inflation rate has a significant relationship with CAR.

Barrell, Karim and Ventouri (2013) investigated the effect of some of the macroeconomic variables on capital adequacy from 1980 to 2012. In this study, current account deficit has significantly affect Capital Adequacy. Other than that, Balogh (2012) studied on macroprudential supervision tools in 27 countries of European banking System from 2001 to 2010. By applying fixed effect model, the result indicated that government deficit/surplus has no significant impact on bank capital to asset ratio. According to Caggiano and Calice (2011), who conducted a study on the macroeconomic determinants of Higher Capital Ratios on African Economies found that current account deficit has statistically no impact on capital Adequacy ratio (CAR). They used fixed effect model to analyze the data.

Past studies have also revealed money supply as one of the important determinants that affect banks capital adequacy ratio. Shaddady and Moore (2015) has analyzed the bank 
regulation, bank specific indicators, country indicators and market contestability indicators determinants of bank capital adequacy ratio inn GCC countries by using panel data for 89 banks during the year 1998 to 2013. They employed A GMM estimator in the study and the results revealed that money supply has negative and significant impacts on the capital adequacy ratio in large banks. This means that an increase in supply of money will cause large banks to hold low capital adequacy. Moreover, Williams (2011) had studied on the relationship between capital base and macroeconomic, financial structure and banking variables in Nigeria from 1980 to 2008. In the study he is using capital adequacy base as a dependent variable while total loans, money supply, interest rate, inflation rate, demand deposit, political instability, exchange rate, liquidity risk, openness of the economy and investments are used as independent variables. By using an error correction model, the empirical finding concluded that the money supply is very important to determine capital adequacy base and having a very strong significant impact on capital adequacy base.

By applying the ordinary least square (OLS) method, Shingjergji and Hyseni (2015) studied the influence of macroeconomic and banking factors on credit growth in the Albanian banking system. The empirical result showed that credit growth is positively related to capital adequacy ratio. Igan and Tan (2015) studied about capital Inflows, credit growth and financial system. This study covered granular panel dataset for 33 countries from 1980 to 2011 . The empirical result showed that credit growth has negative relationship with capital adequacy ratio. The stronger the credit growth, the lower the capital adequacy ratio. This was supported by Trenca et al. (2013) who studied about a macroprudential supervision model in the central and eastern European banking system. One of their research objectives is to identify the macroeconomic variables that have a significant influence on the bank capital to asset ratio among 10 banks during 2000 to 2011. By using fixed effect model, the result showed that domestic credit to private sector in GDP has negative effect on bank capital to asset ratio.

Teglio, Raberto and Cincotti (2011) studied the impact of bank's capital adequacy regulation on the economic system based on a set of 40 years simulation. They examined the data base on short run (first 5 years), medium run (the following 15 years) and long run (the last 20 years). The result pointed that the unemployment rate has a significant impact on bank's capital adequacy ratio. Williams (2011) had studied the relationship between capital base and some macroeconomic variables, financial structure and banking variables over the period of 1980 to 2008 in Nigeria. 
Table 1. the theoretical research on an institutional framework of macroprudential policy

\begin{tabular}{|c|c|}
\hline Name of Authors & Findings \\
\hline Borio (2010), Vinal (2011), Lim et al. (2011) & $\begin{array}{l}\text { Certain aspects that are more importants to } \\
\text { ensure effective instutional framework of } \\
\text { macroprudential policy in a country that are a } \\
\text { clear definition of macroprudential } \\
\text { authorities and mandates, outlined principle } \\
\text { for their work and different configuration of } \\
\text { the mandates distribution between } \\
\text { organizations need to be considered with or } \\
\text { without interagency financial stability board }\end{array}$ \\
\hline $\begin{array}{l}\text { Claessens et al. (2014), Akinci and Olmstead- } \\
\text { Rumsey (2015) }\end{array}$ & $\begin{array}{l}\text { It contains some recommendations on } \\
\text { possible sets of macroprudentials } \\
\text { instruments, condition and objectives for } \\
\text { application of each of instruments. Many of } \\
\text { researchers from IMF tend to view the } \\
\text { macroprudential policy mandate as a right for } \\
\text { macroprudential policy for ensuring financial } \\
\text { stability }\end{array}$ \\
\hline Kama, Adigun and Adegbe (2013) & $\begin{array}{l}\text { The success of the implementation } \\
\text { macroprudential policy need a good } \\
\text { governance arrangement, essential analytical } \\
\text { tools, good coordinating structure as well as } \\
\text { accountability. They are also stated that A } \\
\text { centralised authority should fully control the } \\
\text { policy instruments under a clear mandate, } \\
\text { central banks should play a leading role. }\end{array}$ \\
\hline Lim, Ramchand, Wang and Wu (2013) & $\begin{array}{l}\text { The ownership of a mandate for } \\
\text { macroprudential policy or financial stability, } \\
\text { existence of a financial stability committee } \\
\text { that facilitates policy coordination and } \\
\text { exchange of views among multiple agencies } \\
\text { and the roles a central bank and a } \\
\text { government play in the financial stability } \\
\text { committee are the three characteristics of } \\
\text { institutional arrangement that need to have a } \\
\text { special attention by a central bank and a } \\
\text { government in implementing } \\
\text { macroprudential policy framework. }\end{array}$ \\
\hline
\end{tabular}


Egawa et al. (2015)

Their empirical analyses suggested that, there are the differences in terms of the roles the central bank and the government play in macroprudential policy in each country. Factors that influence these differences included economic and financial characteristics for an example the exchange rate regime and the degree of democracy.

Table 2. Empirical Research on The Effectiveness Of Macroprudential Policy Tools.

\begin{tabular}{|c|c|}
\hline Name of Authors & Findings \\
\hline Ahuja and Nabar (2011) & $\begin{array}{l}\text { Loan to value ratio caps were decelerate the } \\
\text { property price growth and lending growth. } \\
\text { Loan to value ratio (LTV) also strengthen the } \\
\text { bank capital buffers, bank performance and } \\
\text { have a significant effect on financial stability } \\
\text { indicators in economies. }\end{array}$ \\
\hline Igan and Kang (2011) & $\begin{array}{l}\text { There is an evidence of beneficial effects of } \\
\text { LTV and DTI limits associated with a decline in } \\
\text { house price appreciation and transaction } \\
\text { activity in Korea. Both tools also play a key } \\
\text { role in bubble dynamics }\end{array}$ \\
\hline Lim et al. (2011) & $\begin{array}{l}\text { Macroprudential policy tools, mainly based } \\
\text { on credit-related measures (e.g. LTV caps) or } \\
\text { liquidity-related measures (e.g. reserve } \\
\text { requirements) may reduce procyclicality. }\end{array}$ \\
\hline Dell'Ariccia, Igan, Laeven and Tong (2012) & $\begin{array}{l}\text { Some macro-prudential policies tools being } \\
\text { effective in reducing the pro-cyclicality of } \\
\text { credit and leverage in their study }\end{array}$ \\
\hline Claessens et al. (2014) & $\begin{array}{l}\text { Macroprudential policies tools caps on } \\
\text { borrower such as LTV and caps on bank's } \\
\text { asset and liabilities effectively or significantly } \\
\text { reduce the total leverage growth and total } \\
\text { asset growth while buffer-based policies } \\
\text { seems to have little impact on asset growth. }\end{array}$ \\
\hline Aiyar, Calomiris and Wieladek (2014) & $\begin{array}{l}\text { Bank-specific higher capital adequacy } \\
\text { requirements diminished lending by } \\
\text { individual banks (whereas tighter monetary } \\
\text { policy did not affect the supply of lending) }\end{array}$ \\
\hline Aysan et al. (2016) & $\begin{array}{l}\text { Macroprudential measures have a positive } \\
\text { effect on financial stability after the } 2008 \\
\text { crisis. Moreover, depositor discipline varies } \\
\text { across bank types. While state-owned banks }\end{array}$ \\
\hline
\end{tabular}




\begin{tabular}{|l|l|}
\hline Olszak, Kowalska, and Roszkowska (2018) & $\begin{array}{l}\text { appear to have similar disciple with private } \\
\text { counterbanks, Islamic banks have looser } \\
\text { discipline }\end{array}$ \\
\hline $\begin{array}{l}\text { This paper shows that borrower restrictions } \\
\text { (such as loan-to-value ratios - LTV, and debt- } \\
\text { to-income ratios - DTI) are definitely more } \\
\text { effective in reducing the procyclicality of } \\
\text { loan-loss provisions. }\end{array}$ \\
\hline
\end{tabular}

\section{Data and Methodology}

In this study several macroeconomic variables and macroprudential policy elements are used to explain capital adequacy ratio. These macroeconomic variables are GDP growth rate, inflation rate, balance of payment, money supply, domestic credit growth, unemployment rate and real exchange rate. Next is the macroprudential policy elements which consist of macroprudential policy tools that are loan to value ratio (LTV) where it is the ratio of loan amount to total asset, debt to income ratio (DTI) is the ratio of total recurring monthly debt to gross monthly income and reserve requirement (RR) is the fraction of deposits that regulators require a bank to hold in reserves. For mandate, it is the powers of the agency (or agencies) or authority to decide involved in macroprudential policy. There are two indices that are used to represent mandate that are the CB index and the Gov index where below assign a score of 1 to 3, with the higher value indicating the more important role. Table 3 shows the indices and score.

Table 3. The CBINDEX, The GOVINDEX and its score

\begin{tabular}{|l|c|}
\hline \multicolumn{1}{|c|}{ THE CB INDEX } & SCORE \\
\hline $\begin{array}{l}\text { The macroprudential policy/financial stability mandate is } \\
\text { shared by multiple agencies including the central bank, } \\
\text { and the central bank is a member of the financial } \\
\text { stability committee }\end{array}$ & 2 \\
\hline $\begin{array}{l}\text { The mandate is shared by multiple agencies including } \\
\text { the central bank, and the central bank chairs the } \\
\text { financial stability committee }\end{array}$ & 3 \\
\hline $\begin{array}{l}\text { The central bank, or a committee of the central bank, is } \\
\text { the sole owner of the mandate. }\end{array}$ & SCORE \\
\hline \multicolumn{1}{|c|}{ THE GOV INDEX } & 1 \\
\hline $\begin{array}{l}\text { There is no financial stability committee, or no } \\
\text { governmental agency is a member }\end{array}$ & 2 \\
\hline $\begin{array}{l}\text { A governmental agency is a member/observer of the } \\
\text { financial stability committee }\end{array}$ & 3 \\
\hline $\begin{array}{l}\text { A governmental agency chairs the financial stability } \\
\text { committee }\end{array}$ & \\
\hline
\end{tabular}

Source: Egawa et al (2015) 
For transparency it represented by regulation and transparency index. According to Mendonca, Galvao and Loures (2010), economic and political transparencies are more relevant concerning the analysis of the financial system stability. Regulation and transparency index", the economic transparency was divided into two subgroups. The first group is focused on the risks of the financial firms while the second one concentrates on the account information. Table 3.5 shows the method for calculating the degree of transparency and regulation of the financial institutions.

The responses to the questions in Table 4. were classified based on the following criteria:

i. degree " 1 " is attributed to the institutions when the activity under consideration (from A.1.1 to B4) is an exigency determined by the regulatory agencies.

ii. degree " 0.5 " is attributed to the institutions when, although the activity is not an exigency of regulatory agencies, the banking institution performs it in a regular manner

iii. degree " 0 " is attributed to the institutions when neither the institution performs the activity nor it is an exigency of the regulatory agencies.

Table 4. Regulation and transparency Index

\begin{tabular}{|l|l|l|}
\hline Code & Questions & Degree \\
\hline A & Economic transparency & \\
\hline A.1 & $\begin{array}{l}\text { Regarding the institutional risks and principles of } \\
\text { Basel II }\end{array}$ & \\
\hline A.1.1 & If the institution calculates the credit risk & $0,0.5$ or 1.0 \\
\hline A.1.2 & If the credit risk is disclosed in periodic reports & $0,0.5$ or 1.0 \\
\hline A.1.3 & If the institution calculates the market risk & $0,0.5$ or 1.0 \\
\hline A.1.4 & If the market risk is disclosed in periodic reports & $0,0.5$ or 1.0 \\
\hline A.1.5 & If the institution calculates the operational risk & $0,0.5$ or 1.0 \\
\hline A.1.6 & If the operational risk is disclosed in periodic reports & $0,0.5$ or 1.0 \\
\hline A.2 & $\begin{array}{l}\text { Regarding the account information and policy of } \\
\text { transparency }\end{array}$ & \\
\hline A.2.1 & If the reports are available quarterly & $0,0.5$ or 1.0 \\
\hline A.2.2 & If the reports are available yearly & $0,0.5$ or 1.0 \\
\hline A.2.3 & $\begin{array}{l}\text { If the Basel index is calculated and disclosed in the } \\
\text { reports }\end{array}$ & $0,0.5$ or 1.0 \\
\hline B & Political transparency & $0,0.5$ or 1.0 \\
\hline B.1 & $\begin{array}{l}\text { If the capital structure of the institution is disclosed } \\
\text { in the account reports }\end{array}$ & $0,0.5$ or 1.0 \\
\hline B.2 & $\begin{array}{l}\text { If the structure and risk management policies are } \\
\text { disclosed }\end{array}$ & 0,0 or 1.0 \\
\hline B.3 & If the policies for mitigating risk (hedge) are disclosed & $0,0.5$ or 1.0 \\
\hline B.4 & If market environments and forecasts are disclosed & $0,0.5$ on \\
\hline
\end{tabular}


The research period is from 2008 to 2017. Islamic banking data have been collected from Islamic banks in Bahrain, Bangladesh, Brunei, Egypt, Indonesia, Iran, Jordan, Kuwait, Lebanon, Malaysia, Nigeria, Oman, Pakistan, Palestine, Qatar, Saudi Arabia, Sudan, Tunisia, Turkey and United Arab Emirates (UAE).

\section{Research Framework}

The theoretical framework in this study is based on Babihuga (2007), Trenca et al. (2013) and Ismail and Che Pa (2015). 
Figure 1. Relationships between Macroeconomic Variables, Macroprudential policy elements and Capital Adequacy Ratio

Independent Variables

Macroeconomic Variables

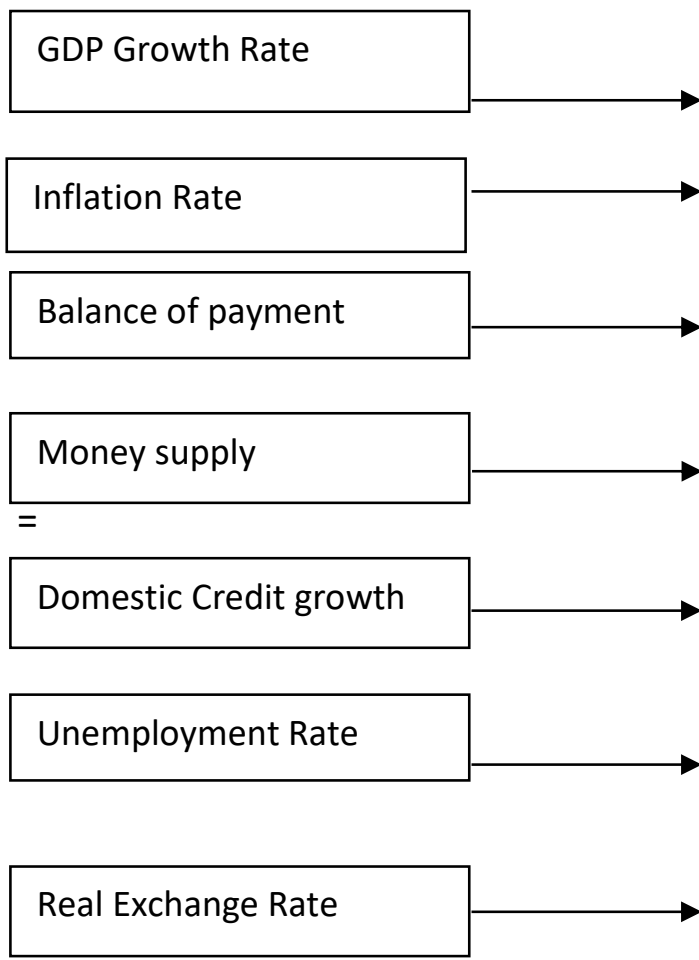

Macroprudential Policy Elements

$$
\text { Loan to Value Ratio (LTV) }
$$

Debt to Income Ratio

(DTI)

\section{Reserve Requirement} (RR)

\section{Mandate}

Transparency and

Accountabilitv

\section{Dependent Variable}

Macroprudential Indicator
Capital adequacy ratio (Bank Capital to risk weighted asset) 


\section{Result and Discussion}

Panel Data analysis was employed in verifying the relationship exists between macroeconomic variables, macroprudential policy elements with capital adequacy ratio in Islamic bank. The unbalanced panel data analysis was used for the estimation. To do this analysis two Stages Least Square Model had be done in order to get a good result that are supported by the previous studies. In general, if there are more time- varying exogenous variables than timeinvariant endogenous variables, two stage least square estimator is consistent and more effiecient than the within estimator. Two stage least squares method is used fit models that include instrumental variables. 2SLS includes four types of variable(s): dependent, exogenous, endogenous, and instrument. In this study, instrumented variable is CG, included instruments variables are GDP, BOP, MS, UNR and TRANS and excluded instruments are INF AND RER. Since the data collected consist of time variant variables and time invariant variable (LTV, DTI, CBINDEX and GOVINDEX), the data had divided into four (4) models.

Model A

CAR $i, t=\beta 0+\beta 1 G D P i, t+\beta 2 I N F i, t+\beta 3 B O P i, t+\beta 4 M S i, t+\beta 5 C G i, t+\beta 6 U N R i, t+\beta 7 R E R i, t+\beta 8 L T V i, t$ $+\beta 9 R R i, t+\beta 10 C B I N D E X i, t+\beta 11$ TRANSi, $t+\varepsilon i, t$

Model B

CAR $i, t=\beta 0+\beta 1 G D P i, t+\beta 2 I N F i, t+\beta 3 B O P i, t+\beta 4 M S i, t+\beta 5 C G i, t+\beta 6 U N R i, t+\beta 7 R E R i, t+\beta 8 D T I i, t$ $+\beta 9 R R i, t+\beta 10 C B I N D E X i, t+\beta 11$ TRANSi,t

Model C

CAR $i, t=\beta 0+\beta 1 G D P i, t+\beta 2 I N F i, t+\beta 3 B O P i, t \quad \beta 4 M S i, t+\beta 5 C G i, t+\beta 6 U N R i, t+\beta 7 R E R i, t+\beta 8 L T V i, t$

$+\beta 9 R R i, t+\beta 10 G O V I N D E X i, t+\beta 11$ TRANSi, $t+\varepsilon i, t$

Model D

CAR i, $t=\beta 0+\beta 1$ GDPi, $t+\beta 2$ INFi, $t+\beta 3 B O P i, t+\beta 4 M S i, t+\beta 5 C G i, t+\beta 6 U N R i, t+\beta 7 R E R i, t+$ $\beta 8 D T I i, t+\beta 9 R R i, t+\beta 10 G O V I N D E X i, t+\beta 11$ TRANSi,t 


\section{Descriptive Statistic Analysis}

Table 5.Descriptive Statistic Analysis

\begin{tabular}{|c|c|c|c|c|c|c|}
\hline VARIABLES & Mean & Median & $\begin{array}{l}\text { Standard } \\
\text { Deviation }\end{array}$ & Skewness & Kurtosis & Jarque-Bera \\
\hline CAR & 18.27613 & 16.50000 & 9.783380 & 3.932527 & 23.12471 & $\begin{array}{l}3773.811 \\
(0.000000) \\
\end{array}$ \\
\hline GDP & 3.977145 & 4.120500 & 3.507753 & 0.312210 & 6.217899 & $\begin{array}{l}89.53978 \\
(0.000000)\end{array}$ \\
\hline INF & 6.677755 & 4.456000 & 7.227234 & 2.075975 & 8.392552 & \begin{tabular}{|l|l}
385.9859 \\
$(0.000000)$ \\
\end{tabular} \\
\hline BOP & 3.436111 & -0.050500 & 16.22399 & 1.829550 & 10.52151 & $\begin{array}{l}577.1881 \\
(0.000000) \\
\end{array}$ \\
\hline MS & 15.75658 & 12.41900 & 15.51736 & 2.509713 & 10.06239 & $\begin{array}{l}622.4722 \\
(0.000000) \\
\end{array}$ \\
\hline CG & 52.57373 & 46.54850 & 28.49519 & 0.526255 & 2.720509 & $\begin{array}{l}9.783627 \\
(0.007508) \\
\end{array}$ \\
\hline UNR & 7.347885 & 5.600000 & 5.474515 & 0.976482 & 3.462395 & $\begin{array}{l}33.56566 \\
(0.000000) \\
\end{array}$ \\
\hline RER & 103.9251 & 102.4500 & 12.11416 & 0.274564 & 4.594354 & $\begin{array}{l}19.31214 \\
(0.000064) \\
\end{array}$ \\
\hline CBINDEX & 2.600000 & 3.000000 & 0.584558 & -1.150049 & 3.314879 & $\begin{array}{l}44.91336 \\
(0.000000) \\
\end{array}$ \\
\hline GOVINDEX & 2.150000 & 2.000000 & 0.357967 & 1.960392 & 4.813137 & $\begin{array}{l}156.4142 \\
(0.000000)\end{array}$ \\
\hline TRANS & 8.735000 & 8.500000 & 1.676703 & 0.338508 & 1.622356 & $\begin{array}{l}19.63543 \\
(0.000054) \\
\end{array}$ \\
\hline LTV & 77.36842 & 80.00000 & 10.46137 & -0.571049 & 4.245173 & $\begin{array}{l}22.60086 \\
(0.000012) \\
\end{array}$ \\
\hline DTI & 49.53333 & 50.00000 & 10.47763 & 0.168520 & 2.063105 & \begin{tabular}{|l|l}
6.196044 \\
$(0.045138)$ \\
\end{tabular} \\
\hline $\mathrm{RR}$ & 0.090625 & 0.070000 & 0.056487 & 1.388485 & 4.386249 & $\begin{array}{l}80.27709 \\
(0.000000)\end{array}$ \\
\hline
\end{tabular}

Mean shows the average value of the series and median is the middle value (or average of the two middle value) of the series when the value are ordered from the smallest to the largest amount. Positive skewness was represented by CAR, GDP, INF, BOP, MS, CG, UNR, RER, GOVINDEX, TRANS, DTI and RR variables, and implied that the distribution had a long right tail. Meanwhile, CBINDEX and LTV variables showed a negative value of skewness, which indicated that the distribution had a long left tail. The result showed that kurtosis value of CAR, GDP, INF, BOP, MS, UNR, RER, CBINDEX, GOVINDEX, LTV and RR exceeded three. The kurtosis indicated Leptokurtic or the distribution is peaked as compared to normal distribution. The kurtosis value of CG, TRANS and DTI was less than three, implied Platykurtic which defines the distribution is 
flat relative to the normal. Finally $p$ value of Jarque - Bera stated that all variables are equal to 0.000000 except RER (0.000064), TRANS (0.000054), LTV (0.000012) and DTI (0.045138) which is less than 0.05 and it indicates a significant result. Thus, it is not showing normal distribution. 
Table 6. Pearson Correlation Analysis

\begin{tabular}{|c|c|c|c|c|c|c|c|c|c|c|c|c|c|c|}
\hline & CAR & GDP & INF & BOP & MS & CG & UNR & RER & $\begin{array}{l}\text { CBIND } \\
\text { EX }\end{array}$ & $\begin{array}{l}\text { GOVIN } \\
\text { DEX }\end{array}$ & $\begin{array}{l}\text { TRAN } \\
\mathrm{S}\end{array}$ & LTV & DTI & $\mathrm{RR}$ \\
\hline CAR & 1 & $\begin{array}{r}0.138 \\
767\end{array}$ & $\begin{array}{r}- \\
0.027 \\
72\end{array}$ & $\begin{array}{r}0.360 \\
336\end{array}$ & $\begin{array}{r}0.125 \\
863\end{array}$ & $\begin{array}{r}- \\
0.295 \\
81\end{array}$ & $\begin{array}{r}- \\
0.052 \\
31\end{array}$ & $\begin{array}{r}0.236 \\
655\end{array}$ & $\begin{array}{r}0.261 \\
628\end{array}$ & $\begin{array}{r}- \\
0.1220 \\
1\end{array}$ & $\begin{array}{r}0.455 \\
517\end{array}$ & $\begin{array}{r}0.055 \\
416\end{array}$ & $\begin{array}{r}0.324 \\
089\end{array}$ & $\begin{array}{r}0.030 \\
54\end{array}$ \\
\hline GDP & $\begin{array}{r}0.138 \\
767\end{array}$ & 1 & $\begin{array}{r}- \\
0.105 \\
7\end{array}$ & $\begin{array}{r}0.065 \\
755\end{array}$ & $\begin{array}{r}0.260 \\
671\end{array}$ & $\begin{array}{r}- \\
0.168 \\
64\end{array}$ & $\begin{array}{r}- \\
0.056 \\
29\end{array}$ & $\begin{array}{r}0.001 \\
798\end{array}$ & $\begin{array}{r}- \\
0.027 \\
15\end{array}$ & $\begin{array}{r}- \\
0.0741 \\
6\end{array}$ & $\begin{array}{r}0.051 \\
163\end{array}$ & $\begin{array}{r}- \\
0.111 \\
55\end{array}$ & $\begin{array}{r}- \\
0.040 \\
71\end{array}$ & $\begin{array}{r}- \\
0.069 \\
41\end{array}$ \\
\hline INF & $\begin{array}{r}- \\
0.027 \\
72\end{array}$ & $\begin{array}{r}- \\
0.105 \\
7\end{array}$ & 1 & $\begin{array}{r}- \\
0.064 \\
79\end{array}$ & $\begin{array}{r}0.265 \\
118\end{array}$ & $\begin{array}{r}- \\
0.460 \\
2\end{array}$ & $\begin{array}{r}0.225 \\
978\end{array}$ & $\begin{array}{r}0.241 \\
15 \\
\end{array}$ & $\begin{array}{r}0.014 \\
502 \\
\end{array}$ & $\begin{array}{r}0.1621 \\
31\end{array}$ & $\begin{array}{r}- \\
0.220 \\
96\end{array}$ & $\begin{array}{r}0.126 \\
547\end{array}$ & $\begin{array}{r}0.149 \\
147\end{array}$ & $\begin{array}{r}0.203 \\
146\end{array}$ \\
\hline BOP & $\begin{array}{r}0.360 \\
336 \\
\end{array}$ & $\begin{array}{r}0.065 \\
755 \\
\end{array}$ & $\begin{array}{r}- \\
0.064 \\
79 \\
\end{array}$ & 1 & $\begin{array}{r}- \\
0.160 \\
29\end{array}$ & $\begin{array}{r}- \\
0.156 \\
11 \\
\end{array}$ & $\begin{array}{r}- \\
0.523 \\
4\end{array}$ & $\begin{array}{r}0.115 \\
852 \\
\end{array}$ & $\begin{array}{r}0.284 \\
293 \\
\end{array}$ & $\begin{array}{r}0.1756 \\
9 \\
\end{array}$ & $\begin{array}{r}0.624 \\
897 \\
\end{array}$ & $\begin{array}{r}- \\
0.040 \\
53 \\
\end{array}$ & $\begin{array}{r}0.223 \\
567 \\
\end{array}$ & $\begin{array}{r}0.332 \\
79 \\
\end{array}$ \\
\hline MS & $\begin{array}{r}0.125 \\
863 \\
\end{array}$ & $\begin{array}{r}0.260 \\
671 \\
\end{array}$ & $\begin{array}{r}0.265 \\
118 \\
\end{array}$ & $\begin{array}{r}- \\
0.160 \\
29 \\
\end{array}$ & 1 & -0.495 & $\begin{array}{r}0.547 \\
675\end{array}$ & $\begin{array}{r}0.186 \\
675 \\
\end{array}$ & $\begin{array}{r}0.097 \\
413 \\
\end{array}$ & $\begin{array}{r}0.0091 \\
82 \\
\end{array}$ & $\begin{array}{r}- \\
0.286 \\
95\end{array}$ & $\begin{array}{r}0.317 \\
503 \\
\end{array}$ & $\begin{array}{r}0.164 \\
504 \\
\end{array}$ & $\begin{array}{r}0.122 \\
586 \\
\end{array}$ \\
\hline CG & $\begin{array}{r}- \\
0.295 \\
81\end{array}$ & $\begin{array}{r}- \\
0.168 \\
64 \\
\end{array}$ & $\begin{array}{r}- \\
0.460 \\
2\end{array}$ & $\begin{array}{r}- \\
0.156 \\
11 \\
\end{array}$ & -0.495 & 1 & $\begin{array}{r}- \\
0.239 \\
65 \\
\end{array}$ & $\begin{array}{r}- \\
0.327 \\
01 \\
\end{array}$ & $\begin{array}{r}- \\
0.191 \\
14\end{array}$ & $\begin{array}{r}0.0123 \\
3\end{array}$ & $\begin{array}{r}0.101 \\
812 \\
\end{array}$ & $\begin{array}{r}- \\
0.091 \\
24 \\
\end{array}$ & $\begin{array}{r}- \\
0.042 \\
68 \\
\end{array}$ & $\begin{array}{r}- \\
0.077 \\
08 \\
\end{array}$ \\
\hline UNR & $\begin{array}{r}- \\
0.052 \\
31\end{array}$ & $\begin{array}{r}- \\
0.056 \\
29\end{array}$ & $\begin{array}{r}0.225 \\
978\end{array}$ & $\begin{array}{r}- \\
0.523 \\
4\end{array}$ & $\begin{array}{r}0.547 \\
675\end{array}$ & $\begin{array}{r}- \\
0.239 \\
65\end{array}$ & 1 & $\begin{array}{r}0.000 \\
79\end{array}$ & $\begin{array}{r}- \\
0.127 \\
89\end{array}$ & $\begin{array}{r}0.1458 \\
56\end{array}$ & $\begin{array}{r}- \\
0.654 \\
8\end{array}$ & $\begin{array}{r}0.424 \\
251\end{array}$ & $\begin{array}{r}- \\
0.065 \\
79\end{array}$ & $\begin{array}{r}0.081 \\
129\end{array}$ \\
\hline RER & $\begin{array}{r}0.236 \\
655\end{array}$ & $\begin{array}{r}0.001 \\
798\end{array}$ & $\begin{array}{r}0.241 \\
15\end{array}$ & $\begin{array}{r}0.115 \\
852\end{array}$ & $\begin{array}{r}0.186 \\
675\end{array}$ & $\begin{array}{r}- \\
0.327 \\
01\end{array}$ & $\begin{array}{r}0.000 \\
79\end{array}$ & 1 & $\begin{array}{r}0.322 \\
167\end{array}$ & $\begin{array}{r}- \\
0.4328 \\
8\end{array}$ & $\begin{array}{r}0.127 \\
684\end{array}$ & $\begin{array}{r}- \\
0.211 \\
98\end{array}$ & $\begin{array}{r}0.142 \\
957\end{array}$ & $\begin{array}{r}0.236 \\
497\end{array}$ \\
\hline $\begin{array}{l}\text { CBIND } \\
\text { EX }\end{array}$ & $\begin{array}{r}0.261 \\
628\end{array}$ & $\begin{array}{r}- \\
0.027 \\
15\end{array}$ & $\begin{array}{r}0.014 \\
502\end{array}$ & $\begin{array}{r}0.284 \\
293\end{array}$ & $\begin{array}{r}0.097 \\
413\end{array}$ & $\begin{array}{r}- \\
0.191 \\
14\end{array}$ & $\begin{array}{r}- \\
0.127 \\
89\end{array}$ & $\begin{array}{r}0.322 \\
167\end{array}$ & 1 & $\begin{array}{r}- \\
0.7395 \\
1\end{array}$ & $\begin{array}{r}0.323 \\
625\end{array}$ & $\begin{array}{r}0.283 \\
266\end{array}$ & $\begin{array}{r}0.266 \\
622\end{array}$ & $\begin{array}{r}0.236 \\
32\end{array}$ \\
\hline
\end{tabular}




\begin{tabular}{|c|c|c|c|c|c|c|c|c|c|c|c|c|c|c|}
\hline GOVIN & $0.122^{-}$ & $\begin{array}{r}- \\
0.074\end{array}$ & 0.162 & $\begin{array}{r}- \\
0.175\end{array}$ & 0.009 & 0.012 & 0.145 & $\begin{array}{r}- \\
0.432\end{array}$ & $\begin{array}{r}- \\
0.739\end{array}$ & & $\begin{array}{r}- \\
0.229\end{array}$ & $\begin{array}{r}- \\
0.007\end{array}$ & $\begin{array}{r}- \\
0.070\end{array}$ & 0.164 \\
\hline DEX & 01 & 16 & 131 & 69 & 182 & 33 & 856 & 88 & 51 & 1 & 08 & 26 & 77 & 818 \\
\hline & 0.455 & 0.051 & 0.220 & 0.624 & 0.286 & 0.101 & 0.654 & 0.127 & 0.323 & 0.2290 & & 0.060 & 0.455 & 0.346 \\
\hline TRANS & 517 & 163 & 96 & 897 & 95 & 812 & 8 & 684 & 625 & 8 & 1 & 77 & 646 & 46 \\
\hline & 0.055 & $0.111^{-}$ & 0.126 & $\begin{array}{r}- \\
0.040\end{array}$ & 0.317 & 0.091 & 0.424 & 0.211 & 0.283 & 0.0072 & $\begin{array}{r}- \\
0.060\end{array}$ & & 0.556 & 0.556 \\
\hline LTV & 416 & 55 & 547 & 53 & 503 & 24 & 251 & 98 & 266 & 6 & 77 & 1 & 599 & 27 \\
\hline & 0.324 & $0.040^{-}$ & 0.149 & 0.223 & 0.164 & $0.042^{-}$ & 0.065 & 0.142 & 0.266 & $\begin{array}{r}- \\
0.0707\end{array}$ & 0.455 & 0.556 & & 0.247 \\
\hline DTI & 089 & 71 & 147 & 567 & 504 & 68 & 79 & 957 & 622 & 7 & 646 & 599 & 1 & 83 \\
\hline & $0.030^{-}$ & 0.069 & 0.203 & $\begin{array}{r}- \\
0.332\end{array}$ & 0.122 & $\begin{array}{r}- \\
0.077\end{array}$ & 0.081 & 0.236 & 0.236 & 0.1648 & 0.346 & 0.556 & 0.247 & \\
\hline $\mathrm{RR}$ & 54 & 41 & 146 & 79 & 586 & 08 & 129 & 497 & 32 & 18 & 46 & 27 & 83 & 1 \\
\hline
\end{tabular}

Table 6. shows the relationship between macroeconomic variables, macroprudential policy elements and Islamic bank's capital adequacy ratio. GDP, BOP, MS, RER, CBINDEX, TRANS, LTV and DTI are positively correlated with the Islamic bank's capital adequacy ratio. Other than that the result of this pearson correlation analysis for model 1showed that, there was a negative association between INF, CG, UNR, GOVINDEX and RR with Islamic bank's capital adequacy ratio. 
INTERNATIONAL JOURNAL OF ACADEMIC RESEARCH IN BUSINESS AND SOCIAL SCIENCES Vol. 11, No. 8, 2021, E-ISSN: 2222-6990 @ 2021 HRMARS

Table 7. Regression Analysis Result Of Pooled Two (2) Stage Least Squares Estimator Model for Dependent Variable - Capital Adequacy Ratio - (Model A, Model B, Model C and Model D)

\begin{tabular}{|c|c|c|c|c|}
\hline & 2SLS (ROBUST) & 2SLS (ROBUST) & 2SLS (ROBUST) & 2SLS (ROBUST) \\
\hline & $\begin{array}{l}\text { MODEL A } \\
\text { (TI- LTV \& } \\
\text { CBINDEX) }\end{array}$ & $\begin{array}{l}\text { MODEL B } \\
\text { (TI - LTV \& } \\
\text { GOVINDEX) }\end{array}$ & $\begin{array}{l}\text { MODEL C } \\
(\text { TI - DTI \& } \\
\text { CBINDEX })\end{array}$ & $\begin{array}{l}\text { MODEL D } \\
\text { (TI - DTI \& } \\
\text { GOVINDEX) }\end{array}$ \\
\hline Intercept & $\begin{array}{l}-2.81997 \\
(0.013)\end{array}$ & \begin{tabular}{|l}
-3.278215 \\
$(0.017)$
\end{tabular} & $\begin{array}{l}-.0100681 \\
(0.993)\end{array}$ & $\begin{array}{l}-0.5749955 \\
(0.647)\end{array}$ \\
\hline LGDP & \begin{tabular}{|l}
-0.0003201 \\
$(0.994)$
\end{tabular} & $\begin{array}{l}0.0037715 \\
(0.926)\end{array}$ & $\begin{array}{l}0.0580568 \\
(0.116)^{*}\end{array}$ & $\begin{array}{l}0.0700771 \\
(0.048)^{* *}\end{array}$ \\
\hline LINF & & & & \\
\hline LBOP & $\begin{array}{l}0.084852 \\
(0.004)^{* * *}\end{array}$ & $\begin{array}{l}0.0640654 \\
(0.042)^{* *}\end{array}$ & $\begin{array}{l}0.0154364 \\
(0.641)\end{array}$ & $\begin{array}{l}0.0023669 \\
(0.942)\end{array}$ \\
\hline LMS & $\begin{array}{l}0.0290876 \\
(0.562)\end{array}$ & \begin{tabular}{|l|}
0.0517317 \\
$(0.379)$
\end{tabular} & $\begin{array}{l}0.1136994 \\
(0.047)^{* *}\end{array}$ & $\begin{array}{l}0.1092886 \\
(0.056)^{* *}\end{array}$ \\
\hline LCG & $\begin{array}{l}0.0857829 \\
(0.407)\end{array}$ & $\begin{array}{l}0.1134989 \\
(0.325)\end{array}$ & $\begin{array}{l}0.1071735 \\
(0.366)\end{array}$ & $\begin{array}{l}0.1021782 \\
(0.395)\end{array}$ \\
\hline LUNR & \begin{tabular}{|l}
-0.0349929 \\
$(0.164)$ \\
\end{tabular} & $\begin{array}{l}-0.0034028 \\
(0.907)\end{array}$ & $\begin{array}{l}0.0428616 \\
(0.202) \\
\end{array}$ & $\begin{array}{l}0.0752243 \\
(0.022)^{* *}\end{array}$ \\
\hline LRER & & & & \\
\hline LLTV & $\begin{array}{l}0.9471822 \\
(0.000) * * *\end{array}$ & $\begin{array}{l}0.9357908 \\
(0.000)^{* * *}\end{array}$ & & \\
\hline LDTI & & & $\begin{array}{l}-0.083906 \\
(0.597)\end{array}$ & $\begin{array}{l}-0.022951 \\
(0.895)\end{array}$ \\
\hline LRR & $\begin{array}{l}0.1457192 \\
(0.001)^{* * *}\end{array}$ & $\begin{array}{l}0.168205 \\
(0.000)^{* * *}\end{array}$ & $\begin{array}{l}0.1050007 \\
(0.034)^{* *}\end{array}$ & $\begin{array}{l}0.1236697 \\
(0.019)^{* *}\end{array}$ \\
\hline CBINDEX & $\begin{array}{l}0.1463334 \\
(0.047)^{* *}\end{array}$ & & $\begin{array}{l}0.1270952 \\
(0.117)^{*}\end{array}$ & \\
\hline GOVINDEX & & $\begin{array}{l}-0.1890141 \\
(0.041)^{* *}\end{array}$ & & $\begin{array}{l}-0.1035235 \\
(0.170)\end{array}$ \\
\hline TRANS & $\begin{array}{l}0.616677 \\
(0.003)^{* * *}\end{array}$ & $\begin{array}{l}0.8522597 \\
(0.001)^{* * *}\end{array}$ & $\begin{array}{l}1.161904 \\
(0.000)^{* * *}\end{array}$ & $\begin{array}{l}1.377728 \\
(0.000) * * *\end{array}$ \\
\hline Adjusted $\mathrm{R}^{2}$ & 0.9878 & 0.9872 & 0.9879 & 0.9878 \\
\hline F Statistic & \begin{tabular}{|l}
6.22 \\
$(0.0000)$
\end{tabular} & \begin{tabular}{|l}
6.15 \\
$(0.0000)$
\end{tabular} & $\begin{array}{l}5.89 \\
(0.0000)\end{array}$ & $\begin{array}{l}5.58 \\
(0.0000)\end{array}$ \\
\hline Observation & 145 & 145 & 115 & 115 \\
\hline
\end{tabular}


This table provides the regression results of macroeconomic variables, macroprudential policy elements with the Islamic bank's Capital Adequacy Ratio(model A, model B, model C and model D) using Pooled Regression model and two stage least square estimator model. $* * *, * *, *$ significant at the $1 \%, 5 \%$ and $10 \%$ respectively. Standard errors are given in parentheses.

The result in Table 7 for this estimation showed the adjusted R2 for model A, B, C and $D$ are $0.9878,0.9872,0.9879$ and 0.9878 and the $p$ - value of $F-$ statistic is at 0.00000 . This result indicated that the independent variables as a group are significant in determining the dependent variable at $1 \%$ level of significance. For the first macroeconomic variable, the coefficient value of the natural logarithm of GDP growth rate was significantly and uniformly positive for capital adequacy ratio (CAR) at $5 \%$ level. This result showed that GDP growth rate could boost the bank capital. The empirical results of a study conducted by Mili et al. (2014); Schaeck et al (2006); Bohachova (2008) provided the CAR depends significantly on GDP growth of the country where the result indicated that banks in economically advanced countries on average behave more prudently, apparently boosting their capital base during economically good times when it is easiest to do so. The regression result of a study executed by Asarkaya and Ozcan (2007) that studied on the determinants of capital structure in the banking sector from 2002 to 2006 found that economic growth has a positive correlation with capital adequacy ratio where banks seem to hold more capital when economic growth is stronger and banks usually suffer in terms of capital during periods of economic slowdown in Turkey.

Second is BOP where it correlation value was significantly and uniformly positive for capital adequacy ratio (CAR) at $1 \%$ level. This result was consistent with Barrell, Karim and Ventouri (2013) that investigated on the effect of some of the macroeconomic variables on capital adequacy from 1980 to 2012. In this study, current account deficit has significantly affect Capital Adequacy.

Next is Money Supply (MS). The coefficient value of the natural logarithm of money supply (MS) was significantly and uniformly positive for capital adequacy ratio (CAR) at $5 \%$ level. The result was supported by Williams (2011) that studied on the relationship between capital base and macroeconomic, financial structure and banking variables in Nigeria from 1980 to 2008. In the study he is using capital adequacy base as a dependent variable while total loans, money supply, interest rate, inflation rate, demand deposit, political instability, exchange rate, liquidity risk, openness of the economy and investments are used as independent variables. By using an error correction model, the empirical finding concluded that the money supply is very important to determine capital adequacy base and having a very strong significant impact on capital adequacy base. The coefficient and very strong level of significance even at one percent in their result suggested that an increase in Money leads to an increase in Bank capital base. The increase in CAR could also have a feedback effect on economic growth. Another studied by Unvan (2020), showed large supplies of money (BM) have a positive and significant effect on the adequacy of bank assets where the supply of money speeding up economic activity, resulting in more bank deposits for businesses and households. It provides "life support" to banks and allows them to retain enough money to comply with the regulatory requirement. Similar with Jacques and Nigro (1997), where the regulators play a key role in establishing a positive association between capital adequacy ratio and bank efficiency through their activities. Banks could react to administrative activities constraining them, to expand their capital adequacy by expanding resources that was a prevalent thought process in changes in money related frameworks in creating economies. 
The coefficient value the natural logarithm of unemployment rate was significantly and uniformly positive at $5 \%$ level. This result in line with Farooq Akram (2012) that studied about the macro effects of bank capital requirements on Norwegian economy and their use as a macrorudential policy instrument. He found that the unemployment rate has a significant effect on bank capital requirement. Supported by Teglio, Raberto and Cincotti (2011) that studied the impact of bank's capital adequacy regulation on the economic system based on a set of 40 years simulation. They examined the data base on short run (first 5 years), medium run (the following 15 years) and long run (the last 20 years). The result pointed that the unemployment rate has a significant impact on bank's capital adequacy ratio.

In term of macroprudential policy elements, table 7 showed that for the first macroprudential policy tool, the coefficient value of the natural logarithm of loan to value ratio (LTV) was signigicantly and uniformly positive for the CAR at $1 \%$ level. Second tool is Debt to income ratio (DTI) where the result showed DTI had no relationship with CAR, meanwhile the coefficient value of the natural logarithm reserve requirement (RR) had positive impact on the capital adequacy ratio (CAR) at $1 \%$ significance level This result is in line with some previous studies that are showed Some macro-prudential policies tools being effective in stabilising the banking system fragility. Other than that, for mandate there are two index used CBINDEX and GOVINDEX where the coefficient value of CBINDEX was significantly and uniformly positive for capital adequacy ratio (CAR) at $5 \%$ level, Meanwhile, the coefficient value of the GOVINDEX had a negative impact on capital adequacy ratio (CAR) at $5 \%$ significance level. For second macroprudential policy institutional factor, the coefficient value of the natural logarithm of transparency (TRANS) was significantly and uniformly positive for capital adequacy ratio (CAR). This result showed the institutional factors in macroprudential policy framework are effective for ensuring the financial stability.

\section{Conclusion}

The main lesson of Global financial crisis is the importance of mitigating systemic financial risks and the need to strengthen the macroprudential approach to supervision and regulation that can identify risks throughout the system and take appropriate actions to maintain stability. Key elements of an effective macroprudential policy framework consist of a system of early warning indicators that signal increased vulnerabilities to financial stability, a set of policy instruments that can help to contain risks and institutional factors that can be used to ensure the effective identification of systemic risks. Capital Adequacy Ratio is one of the important macroprudential policy indicators on the financial soundness and growth of the Islamic banking systems. The empirical evidences clearly documented that there is statistically significant relationship between the CAR and macroeconomic variables such as Gross Domestic Product, Balance of payment, money supply and unemployment rate. For the effect of macroprudential policy instruments and institutional factors it shows that these elements are effective in stabilising the banking system fragility.

\section{Acknowledgement}

This work was supported by the Universiti Teknologi MARA, Geran Lestari [600-IRMI 5/3/LESTARI (051/2019)]. 


\section{Corresponding Author}

Sutina Binti Junos

Faculty of Business and Management,Universiti Teknologi MARA Cawangan Negeri Sembilan Kampus Rembau, 71300 Rembau, Negeri Sembilan.

Email: sutina@uitm.edu.my

\section{References}

Ahuja, A., \& Nabar, M. (2011). Safeguarding banks and containing property booms: crosscountry evidence on macroprudential policies and lessons from Hong Kong SAR. IMF Working Paper 11/284. Washington, DC: International Monetary Fund.

Aiyar, S., Calomiris, C. W., \& Wieladek, T. (2014). "Does Macro-Prudential Regulation Leak? Evidence from a UK Policy Experiment. Journal of Money, Credit and Banking, 46(1), 181-214.

Akinci, O., \& Olmstead-Rumsey, J. (2015). How effective are macroprudential policies? An empirical investigation. International Finance Discussion Papers, 1136. Retrieved July 6, 2016, from https://www.federalreserve.gov

Aktas, R., Acikalin, S., Bakin, B., \& Calik, G. (2015). The determinants of banks' capital adequacy ratio: Some evidence from South Eastern European countries. Journal of Economics and Behavioral Studies, 7(1), 79-88.

Arvai, Z., Prasad, A., \& Katayama, K. (2014). Macroprudential policy in the GCC countries. IMF Staff Discussion Note SDN/14/01. Washington, DC: International Monetary Fund.

Asarkaya, Y., \& Ozcan, S. (2007). Determinants of capital structure in financial institutions: The case of Turkey. Journal of BRSA Banking and Financial Markets, 1(1), 91-109.

Aysan, A. F., Dolgun, M. H., \& Turhan, M. I. (2014). Assessment of the participation banks and their role in financial inclusion in Turkey. Emerging Markets Finance and Trade, 49(Suppl. 5), 99e111.

Babihuga, R. (2007). Macroeconomic and financial soundness indicators: An empirical investigation. IMF Working Paper 115. Washington, DC: International Monetary Fund.

Balogh, P. (2012). Macroprudential supervision tools in the European banking system. Procedia Economics and Finance, 3, 642-647.

Barrell, R., Karim, D., \& Ventouri, A. (2013). Financial liberalization and capital adequacy in models of financial crises economics and finance. Working Paper 13-06. Retrieved March 10, 2015, from http://www.brunel.ac.uk

Bohachova, O. (2008) : The impact of macroeconomic factors on risks in the banking sector: a cross-country empirical assessment, IAW Diskussionspapiere, No. 44, Institut für Angewandte Wirtschaftsforschung (IAW), Tübingen

Borio, C. (2010). Implementing a macroprudential framework: Blending boldness and realism. Bank for International Settlements.

Caggiano, G., \& Calice, P. (2011). The macroeconomic impact of higher capital ratios on African economies. Working Paper 139, African Development Bank Group.

Calmes, C., \& Theoret, R. (2014). Bank systemic risk and macroeconomic shocks: Canadian and U.S evidence. Journal of Banking \& Finance, 40, 388-402.

Claessens, S., Ghosh, S. R., \& Mihet, R. (2014). Macro-Prudential policies to mitigate financial system vulnerabilities. IMF Working Paper 14/155. Washington, DC: International Monetary Fund. 
Dell'Ariccia, G., Igan, D., Laeven, L., \& Tong, H. (2012). Policies for macrofinancial stability: How to deal with credit booms. IMF staff discussion note SDN 12/06. Washington, DC: International Monetary Fund.

Egawa, E., Otani, A., \& Sakiyama, T. (2015). What determines institutional arrangements for macroprudential policy?.IMES Discussion Paper Series 2015-E-3, Tokyo: Bank of Japan.

Akram, F. Q. (2012). Macro effects of capital requirements and macroprudential policy. Economic Modelling, 42, 77-93.

Hasan, M., \& Dridi, J. (2010).The effects of the global crisis on Islamic and conventional banks: A comparative study. IMF Working Paper 10/201. Washington DC: International Monetary Fund.

Hewaidy, A., and Alyousef, H. (2018), "Bank-Specific and Macroeconomic Determinants of Capital Adequacy Ratio: Evidence from Kuwaiti Banks", European Journal of Economics, Finance and Administrative Sciences, No. 99, pp.5-20.

Igan, D., \& Kang, H. (2011). Do loan-to-value and debt-to-income limits work?. Evidence from Korea. IMF Working paper 11/297. Washington, DC: International Monetary Fund.

Igan, D., \& Tan, Z. (2015). Capital inflows, credit growth, and financial systems. IMF Working Paper 15/19. Washington, DC: International Monetary Fund.

Ioan, T., Balogh, P., \& Simona, M. (2013). A macroprudential supervision model. Empirical evidence from the Central and Eastern European banking system. Retrieved March 9, 2015, from http://steconomiceuoradea.ro/anale/volume/2013/n1/120.pdf, 11131141.

Irawan, K., \& Anggano, A. H. (2015). A study of capital adequacy ratio and its determinants in Indonesian banks: a panel data analysis. Proceedings from31st The IIER International Conference, Bangkok, Thailand.

Ismail, A. G., \& Che Pa, A. S. (2015). Financial soundness indicators and the objectives of shari'ah in assessing the stability of Islamic banks. IRTI Working Paper No 1436-11. The Islamic Research and Teaching Institute: Saudi Arabia.

Jacques, K. T., \& Nigro, P. (1997). Risk-Based Capital, Portfolio Risk, and Bank Capital: A Simultaneous Equations Approach, Journal of Economics and Business 49: 533-547

Kama, U., Adigun, M., \& Adegbe, O. (2013). Issues and challenges for the design and implementation of macro-prudential policy in Nigeria. Occasional Paper 46. Central Bank of Nigeria.

Kawai, M., \& Morgan P. J. (2012). Central banking for financial stability in Asia. Public Policy Review, 8 (3), 215-246.

Krugman, P. (2009). The return of depression economics and the crisis of 2008. New York: Norton.

Lim, C. H., Bhattacharya, R., Columba, F., Costa, A., Otani, A., \& Wu, X. (2011). Macroprudential policy: An organizing framework. IMF Background Paper. Washington, DC: International Monetary Fund.

Lim, C. H., Ramchand, R., Wang, H., \& Wu, X. (2013). Institutional arrangements for macroprudential policy in Asia. IMF Working Paper 13/165. Washington, DC: International Monetary Fund.

Mendonca, H. F., Galvao, D. J. C., \& Loures, R. F. V. (2010). What Is The Importance Of Regulation And Transparency In The Subprime Crisis?. Banks and Bank Systems, 5(1), 32. 
Mili, M., Sahut, J. M., \& Trimeche, H. (2014). Determinants of the capital adequacy ratio of a foreign bank's subsidiaries: The role of the interbank market and regulation of multinational banks. IPAG working papers No 366. IPAG Business School Paris.

Olszak, M., Roszkowska, S., \& Kowalska, I. (2018). Macroprudential policy instruments and procyclicality of loan-loss provisions - Cross-country evidence. Journal of International Financial Markets, Institutions and Money, 54, 228-257.

Shaddady, A., \& Moore, T. (2015). Determinants of capital adequacy ratio in oil exporting countries: Evidence from GCC commercial banks. Proceedings from the Second Middle East Conference on Global Business, Economics, Finance and Banking. Dubai: UAE.

Shingjergji, A., \& Hysen, M. (2015). The Impact of macroeconomic and banking factors on credit growth in the Albanian banking system. European Journal of Economics and Business Studies, 2(1), 113-120.

Teglio, A., Raberto, M., \& Cincotti, S. (2011). The impact of banks' capital adequacy regulation on the economic system: An agent-based. Castellon (Spain) working paper 01. Retrieved April 6, 2015, from https://core.ac.uk/download/pdf/6576840.pdf

Teglio, A., Raberto, M., \& Cincotti, S. (2011). The impact of banks' capital adequacy regulation on the economic system: An agent-based. Castellon (Spain) working paper 01. Retrieved April 6, 2015, from https://core.ac.uk/download/pdf/6576840.pdf

Trenca, I., Balogh, P., \& Mutu, S. (2013). A macroprudential supervision model: Empirical evidence from the Central and Eastern European banking system. Retrieved June 9, 2015, from http://steconomiceuoradea.ro/anale/volume/2013/n1/120.pdf, 11331141.

Unvan, Y. S. (2020). Determinants of Bank Capital Adequacy Ratio in Ghana. Journal of Yasar University, (15/58), 160-166.

Vinals, J. (2011). Macroprudential policy: An organizing framework. Background Paper 1, Washington, DC: International Monetary Fund.

Williams, H. T. (2011). Determinants of capital adequacy in the banking sub-sector of the Nigeria economy: Efficacy of camels. (A model specification with co-integration analysis). International Journal of Academic Research in Business and Social Sciences, 1(3), 234-248.

Yahaya, S. N., Mansor, N., \& Okazaki, K. (2016). Financial performance and economic impact on capital adequacy ratio in Japan. International Journal of Business and Management, 11(4), 14- 